\title{
Transdisciplinary diversity for resolving contemporary problems?
}

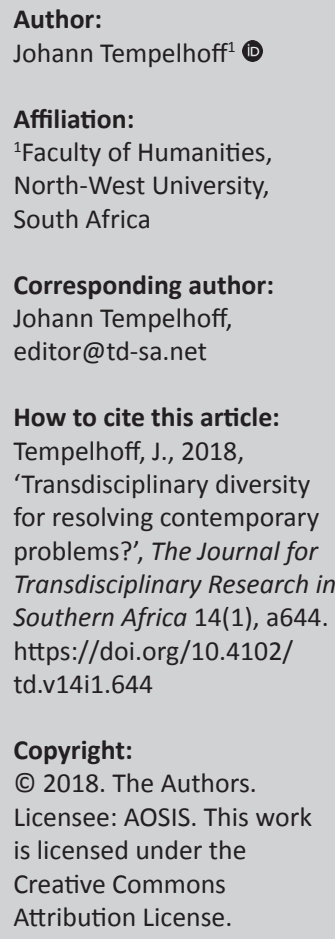

The doors of transdisciplinary research are wide open for those seeking a richer intellectual pastorage beyond the confines of mono-disciplinary studies. One thing is clear from working on the content of this edition of our journal: the material is diverse and covers a broad spectrum of relevant themes.

Few articles can be categorised as the mere product of a mono-disciplinary silo. To be sure, principles of transdisciplinary research are not always clear from the content. Yet, elements deeply seated in transdisciplinary thinking, do come across. There is evidence of authors grappling with critical contemporary issues. Most contributions speak of problems facing contemporary South African society and Africa in the 2010s. Above all, there is consistent evidence of deep reflection in a transdisciplinary mode.

It is apparent that researchers in many fields, exploring methodologies and strategies, rely on aspects of transdisciplinary methodology to find their way through the maze of contemporary thinking in the field. If we are at the present juncture in time a little lost for finding the clear threads of transdisciplinary thinking, rest assured we are not alone.

In a letter, at the start of 2018, to the editor of an international publication, Journal for Cleaner Production, Sakoa and Brambila-Macias asked the question: 'Do we share an understanding of transdisciplinarity in environmental sustainability?' The authors provide a thoughtful assessment of article contributions to the journal on what constitutes transdisciplinary research. They then provide an exposition of disciplinarity, interdisciplinarity and transdisciplinarity before exploring transdisciplinarity from specifically the perspective of environmental sustainability research design (Sakao \& Brambila-Macias 2018). For them, it is clear that not all authors nurture the same views on the practice of transdisciplinarity. Consequently, they suggest, the field of environmental sustainability research should be foregrounded more prominently when authors articulate their work from the use of transdisciplinary tenets in their research. But is this a 'safe and trusted' route to follow?

Categorising transdisciplinarity is seldom uppermost in the minds of scientists and social scientists who seek to understand a variety of perspectives on any given problem. For example, Knierim, Lachewski and Boyarintserva (2018) rely on systems theory to accommodate disciplinary transgression, aimed at absorbing a multitude of actions and points of views of stakeholders and those of the researchers exploring wicked or benign problems in real life.

There is evidence of a growing understanding of what constitutes transdisciplinary research. Colpaert (2018:485), working in the field of computer-assisted language learning, defines transdisciplinarity as:

... the ontological specification of knowledge constructs on a higher, boundary-transcending, level of abstraction.

However, the field remains in an emergent phase of development and requires greater tolerance from disciplinarians. Transdisciplinarity, if we consider its origins way back in the 1970s, is still a young field of academic endeavour. The final destination of transdisciplinarity is perhaps a journey that transcends our present horizon of disciplinary understanding.

Methodologically there remain critical issues. Lamine, for example, cross-examines the field of participatory research activities in transdisciplinarity, which appears to be suspect in some quarters among transdisciplinary methodologists. Despite the potential controversial nature of collective participation and engagement with stakeholders, Lamine is satisfied that the elements of critical thinking and reflection that precedes the process of co-production of knowledge remain in place (Lamine 2018). 
Back to this edition of $T D$, The Journal for Transdisciplinary Research in Southern Africa: there are lots of fertile ideas in the mix on a number of highly topical issues.

South Africa's state system is under scrutiny at the municipal level where monitoring and evaluation systems seem to be amiss. Chigudu seeks to locate corporate governance for sustainability in South Africa's public service. Magagula and Zondok contemplate the strengths and weaknesses of outsourcing core business deliverables in South Africa's stateowned enterprises. Dassah seeks answers for the conundrum of state capture as a governance problem. With memories of the Zuma administration (2009-2018) still very fresh in the public memory, the problem can potentially be resolved by resorting to levels of deeper contemplation. Feeding into the theme of euphemistic understanding, Ndaguba, Ndagubva, Tshiyoyo and Shai explore African philosophical views on corruption. Like philosophers in all parts of the world, since antiquity, we become aware that the jin and yang of Taoist thinking, embracing both the good and the bad, is ever-present in the philosophical objective of locating an understanding of what constitutes reality and truth at any given time and place.

The Western Cape's 'Day Zero' drought event that appears to have come to an end at long last has reverberated in the global news media. We are currently world leaders in terms of recently acquired in situ technical and scientific knowledge, on how to immaculately manage water supplies to a bustling metropolitan city on the African continent in a respectable manner. Working from the examples of Australia's 25-year drought and California's recent dry seasons, South Africa's water sector specialists have made a significant contribution to resolving a brooding conundrum at a time when we grapple with climate change, urbanisation, population growth and an ever-decreasing per capita availability of much needed water on the developing African continent.

In this issue of the journal, Visser explores Cape Town's drought from a historical perspective, with an accent on the political drama that played itself out when the crisis reached a climax. While we are very aware of potable water, there is also a need to contemplate wastewater. We may be using purified wastewater in the near future. Kevin Wall, a respected South African engineer, with many years of research insight, looks at the origins of effluent parameters and the South African regulations on wastewater. It is time for us to take note of these facts for future action plans.

Africa's future depends on the maintenance of order and a peaceful environment conducive to development. In the field of making peace and resolving conflict in Africa, Velthuizen and Ferguson lay down a discourse, in philosophical mode, while Ndaguba reflects on peace operations in Southern Africa and the prospects for a permanent SADC standby force.

Although all the articles published form part of original research, two cutting-edge articles in this issue deserve attention. Kotzé and Senekal's work on gauging the perceptions of minorities in the Twitter messages regarding the Afrikaner community of Orania sheds light on the increasingly important role of social media in South African society.

The second article feeds, from a transdisciplinary perspective, into what is normally associated with the mundane field of humans herding livestock as a profession. Pitikoe's work with practitioners of this ancient occupation in the mountain lands of Lesotho explores the potential for creating learning opportunities among herders. In 2018, an important report was published on South African livestock farming and the threat of predators (Kerley, Wilson \& Balfour 2018). For the meat industry and the food economy of the country in future, the work is important.

However, some civil society organisations have grave concerns about what is considered to be the random and ruthless extermination of wildlife. The report, with a sound contribution on the need for appropriate ethical guidelines to ensure the continued coexistence of predatorial wildlife and commercial livestock on the land, leaves space for more research. It is of vital importance for environmental researchers to explore this field in collaboration with zoologists and botanists.

One alternative to random predator hunting is a $24 / 7$ herding programme on ample and well-cared for grazing lands. South Africa's Landmark Foundation, a non-governmental organisation, headed by Dr Bool Smuts, has been working for some time in the Karoo's Nieuweveld Mountain lands, on a novel experiment of this nature. On 25 November 2018, Landmark Foundation launched the Fair Game Programme. The plan is to win the support of consumers, to pay a little more for Fair Game meat, produced by farmers with an ethical conscience, by respecting the need for wildlife and livestock (under sound herding conditions) to share the land.

Given the fact that certain predator species, such as leopards (Panthera pardus) (McManus 2018), can potentially become extinct in the Eastern and Western Cape, as was the case with the Cape Lion (Panthera leo melanochaita) in the mid-19th century, there is good reason for exploring alternative strategies. For transdisciplinary researchers, there are ample opportunities to make valuable out-of-the-box contributions to resolving problems related to Africa's rapidly diminishing wildlife heritage.

\section{References}

Colpaert, J., 2018, 'Transdisciplinarity revisited', Computer Assisted Language Learning 31(5-6), 483-489. https://doi.org/10.1080/09588221.2018.1437111

Kerley, G., Wilson, S. \& Balfour, D. (eds.), 2018, Livestock predation and its management in South Africa: A scientific assessment, Centre for African Conservation Ecology, Nelson Mandela University, Port Elizabethg.

Knierim, A., Lachewski, L. \& Boyarintserva, O., 2018, 'Inter- and transdisciplinarity in Bioeconomy', Chapter 4, in I. Lewandowski (ed.), Bioeconomy: Shaping the transition to a sustainable biobased economy, pp. 39-74, Springer, Cham.

Lamine, C., 2018, 'Transdisciplinarity in research about agrifood systems transitions: A pragmatist approach to processes of attachment', Sustainability 10(4), 1241. https://doi.org/10.3390/su10041241

Mcmanus, J., 2018, 'Conservation of leopards (Panthera pardus) in the Eastern and Western Cape, South Africa: Investigating the effect of land use, gene flow and connectivity', University of the Witwatersrand.

Sakao, T. \& Brambila-Macias, S., 2018, 'Do we share an understanding of transdisciplinarity in environmental sustainability research?', Journal of Cleaner Production 170(1), 1399-1403. https://doi.org/10.1016/j.jclepro.2017.09.226 